\title{
ANALISIS POLA DAN STRATEGI PENYEDIAAN PANGAN RUMAH TANGGA PETANI HUTAN KEMASYARAKATAN KABUPATEN LAMPUNG BARAT
}

\author{
(Analysis of Food Supplying Pattern and Strategy of Social Forestry's Farmer Household \\ in West Lampung District) \\ Rini Nurindarwati ${ }^{1}$, Sri Anna Marliyati ${ }^{2}$, dan Yayat Heryatno ${ }^{2}$ \\ ${ }^{1}$ Program Studi Manaj emen Ketahahan Pangan (MKP), Sekolah Pascasarjana, IPB. \\ 2 Departemen Gizi Masyarakat, Fakultas Ekologi Manusia (FEMA), IPB \\ Tel: 0251-8628304/ 8621258; Fax: 0251-8625846/8622276.
}

\begin{abstract}
The main objective of this study is to provide information about food supplying pattern and strategy of Social Forestry's farmer household. This study was conducted in October 2008 by using cross sectional study design. The sample was 90 Social Forestry's farmer households. The data obtained by the research were household characteristics; food supplying pattern and strategy which analyzed descriptively and inferentially. More than half of the samples (78\%) are small households with all farmers and housewives are in productive age. The income per capita per month of the sample is Rp509 626. The food expenditure per capita per month is Rp213 136, while non food expenditure per capita per month is Rp197 851. The larger shares of food expenditure are utilized in food supplying of cereals (31.7\%), vegetables and fruits $(20.3 \%$, and animal food (18.5\%). Strategies for raising income conducted by the sample are searching supplementary income other than the main working field; conducting husbandry; and planting crops in garden. Saving is a strategy rarely conducted by the sample. Energy supplying of the sample for cereals, vegetables and fruits, oils and fats, sugar, and others are sufficient, while energy supplying for tubers, animal protein, legumes, and oily seed are not sufficient. The food supply is obtained by purchasing $(70.8 \%)$, self production $(28.2 \%)$, and other sources $(0.4 \%)$.
\end{abstract}

Keywords: food supplying pattern, food supplying strategy, social forestry's farmer.

\section{PENDAHULUAN}

Program Hutan Kemasyarakatan (HKm) memberikan peluang kepada masyarakat yang sudah mengelola kawasan hutan untuk mengambil manfaat hasil hutan bukan kayu dengan kewajiban menjaga kelestarian fungsi hutan. Program HKm memberikan aturan-aturan pembatas dalam pola penanaman dan pengelolaan kawasan, sehingga pemanfaatan kawasan untuk pemenuhan kebutuhan pangan juga menjadi terbatas.

Kondisi tersebut dapat menyebabkan tidak terjaminnya penyediaan pangan setiap waktu di tingkat rumah tangga petani HKm. Di era otonomi daerah sekarang ini Pemerintah Daerah Kabupaten Lampung Barat memerlukan informasi tentang pola penyediaan pangan dan strategi penyediaan pangan yang ada pada rumah tangga petani HKm. Informasi ini penting untuk merencanakan kebijakan dan program kehutanan yang mendukung ketahanan pangan petani $\mathrm{HKm}$, yang memanfaatkan hutan dengan menanam kopi.
Penelitian ini bertujuan untuk mengetahui pola dan strategi penyediaan pangan rumah tangga petani HKm di Kabupaten Lampung Barat.

\section{METODE PENELITIAN}

\section{Desain dan Waktu Penelitian}

Penelitian ini menggunakan desain cross sectional study, dilakukan pada bulan Oktober 2008.

\section{Penarikan Contoh}

Contoh penelitian ialah rumah tangga petani $\mathrm{HKm}$ dengan ukuran sampel 90 rumah tangga.

\section{Lenis dan Cara Penqumpulan Data}

Data primer dikumpulkan melalui wawancara dengan kuesioner meliputi: 1) data karakteristik rumah tangga, 2) strategi penyediaan pangan rumah tangga, dan 3) pola pe- 
nyediaan pangan (sumber dan biaya penyediaan pangan menurut jenis dan jumlah pangan yang tersedia).

\section{Pengolahan dan Analisis Data}

Data diolah dan dianalisis secara deskriptif dan inferensia. Strategi penyediaan pangan yang dianalisis adalah upaya yang dilakukan untuk memenuhi kebutuhan pangan rumah tangga. Tingkat ketersediaan pangan rumah tangga dianalisis secara kuantitatif (dengan membandingkan ketersediaan aktual dan ideal) dan kualitatif (dengan pendekatan PPH/ Pola Pangan Harapan).

\section{HASIL DAN PEMBAHASAN}

\section{Karakteristik Rumah tangga Responden}

Rumah tangga petani $\mathrm{HKm}$ rata-rata beranggota 4 orang, $78 \%$ rumah tangga merupakan rumah tangga kecil, dengan kepala dan ibu rumah tangga pada usia produktif dan pendidikan formal setingkat SD. Pekerjaan utama kepala rumah tangga adalah petani di lahan $\mathrm{HKm}$, dengan pekerjaan sampingan beternak $(12.2 \%)$, buruh $(51.1 \%)$, pedagang $(10 \%)$, mengoj ek (20\%) dan lainnya (6.7\%).

Pendapatan rumah tangga petani $\mathrm{HKm}$ sebesar Rp. 509 626/ kapita/bulan berasal dari usaha tani HKm (Rp. 327 452/ kapita/bulan) dan usaha non HKm (Rp. 182 174/ kapita/ bulan). Standar garis kemiskinan wilayah pedesaan Propinsi Lampung adalah Rp. 145 634/ kapita/bulan (BPS, 2008), sehingga diketahui bahwa seluruh rumah tangga petani $\mathrm{HKm}$ berpendapatan di atas garis kemiskinan. Pengeluaran rumah tangga petani $\mathrm{HKm}$ rata-rata per kapita per bulan Rp. 410987 dengan rincian pengeluaran pangan Rp. 213136 dan non pangan Rp. 197851.

Strategi Rumah tangga Petani HKm Dalam Penyediaan Pangan

Puspitawati (1998) membagi strategi rumah tangga untuk mempertahankan ketahanan pangannya menjadi dua yaitu strategi penambahan pendapatan (Income Generating Strategy) dan strategi penghematan (CuttingBack Expenses). Upaya peningkatan pendapatan yang paling banyak dilakukan rumah tangga petani HKm adalah bekerja di luar pekerjaan utama (buruh tani, buruh bangunan, tukang ojek dan buruh pabrik), sehingga perlu disediakan lapangan pekerjaan di sekitar kawasan hutan, terutama pekerjaan musiman. Selanjutnya sebaran rumah tangga petani $\mathrm{HKm}$ menurut jenis strategi upaya peningkatan pendapatan dalam rangka penyediaan pangan dapat dilihat pada Tabel 1.

Rumah tangga petani $\mathrm{HKm}$ yang meningkatkan pendapatannya dengan beternak kambing dan ayam juga cukup tinggi karena jenis ternak tersebut mudah dijual setiap saat dan kotorannya dapat dimanfaatkan sebagai pupuk. Namun karena jumlah ternak tersebut masih sedikit maka perlu dilakukan bimbingan dan pembinaan budidaya ternak. Sebagian rumah tangga petani $\mathrm{HKm}$ juga melakukan strategi dengan menanam tanaman pangan di kebun. Namun masih diperlukan pembinaan yang intensif tentang budi daya tanaman pangan dan pola tanam tumpangsari. Pengembangan tanaman pangan di kebun/lahan garap perlu dikaji lebih lanjut untuk pemilihan jenis tanaman yang sesuai dengan spesifik lokasi di sekitar kawasan hutan dan sesuai dengan sistem tumpangsari.

Tabel 1. Sebaran Rumah Tangga Petani HKm menurut Frekuensi Strategi Upaya Peningkatan Pendapatan dalam Penyediaan Pangan

\begin{tabular}{|c|c|c|c|c|c|c|c|}
\hline \multirow{2}{*}{ No } & \multirow{2}{*}{ Jenis strategi } & \multicolumn{2}{|c|}{ Tidak } & \multicolumn{2}{|c|}{ J arang } & \multicolumn{2}{|c|}{ Sering } \\
\hline & & $\mathbf{n}$ & $\%$ & $\mathbf{n}$ & $\%$ & $\mathbf{n}$ & $\%$ \\
\hline 1 & $\begin{array}{l}\text { Mencari tambahan pendapatan untuk membeli pangan dengan } \\
\text { cara bekerja di luar pekerjaan utama }\end{array}$ & 17 & 18.8 & 24 & 26.6 & 49 & 54.4 \\
\hline 2 & $\begin{array}{l}\text { Mencari tambahan pendapatan dengan menanam tanaman yang } \\
\text { dapat dimakan di kebun/lahan garap }\end{array}$ & 11 & 12.2 & 37 & 41.1 & 42 & 46.6 \\
\hline 3 & Mencari tambahan pendapatan dengan beternak & 37 & 41.1 & 7 & 7.7 & 46 & 51.1 \\
\hline 4 & Menggadaikan aset untuk membeli pangan & 88 & 97.7 & - & - & 1 & 1.1 \\
\hline 5 & Menjual aset untuk membeli kebutuhan pangan & 84 & 93.3 & 4 & 4.4 & 2 & 2.2 \\
\hline 6 & $\begin{array}{l}\text { Meminjam uang kepada rumah tangga/ teman untuk membeli } \\
\text { pangan }\end{array}$ & 47 & 52.2 & 30 & 33.3 & 13 & 14.4 \\
\hline 7 & Membeli pangan dengan hutang & 57 & 63.3 & 22 & 24.4 & 11 & 12.2 \\
\hline 8 & Migrasi ke daerah lain untuk mencari pekerjaan lain & 81 & 90.0 & 8 & 8.8 & 1 & 1.1 \\
\hline
\end{tabular}


Selain upaya peningkatan pendapatan, upaya untuk mempertahankan ketahanan pangan rumah tangga adalah berupa strategi penghematan. Secara rinci sebaran rumahtangga petani $\mathrm{HKm}$ menurut jenis strategi melalui upaya penghematan dalam rangka penyediaan pangan dapat dilihat pada Tabel 2.

Upaya penghematan jarang dilakukan oleh rumah tangga petani HKm. Hal ini diduga karena pola makan tiga kali sehari dengan menyediakan jenis pangan yang tersedia di pasar dan mudah diakses. Sebagai contoh mereka lebih sering menyediakan ikan asin daripada ikan segar, telur ataupun daging karena harganya yang relatif lebih murah dan mudah diperoleh. Upaya penghematan lain yang dilakukan adalah telur hanya diberikan untuk anak-anak balita dan anak usia sekolah, kebutuhan sayur dan buah dapat dicukupi dari hasil kebun mereka.

\section{Ketersediaan Pangan Rumah tangga Petani $\underline{\mathrm{HKm}}$}

Ketersediaan pangan di rumah tangga petani $\mathrm{HKm}$ dalam penelitian ini diukur dari jumlah bahan pangan yang tersedia selama setahun dalam $\mathrm{kg} /$ tahun dan kemudian dikonversi ke dalam ukuran kg/kapita/tahun. Penyediaan beras di tingkat rumah tangga petani $\mathrm{HKm}$ relatif tinggi, hal ini diduga karena beras merupakan bahan pangan pokok yang umumnya dikonsumsi tiga kali sehari. Jenis pangan lainnya yang cukup banyak disediakan rumah tangga petani $\mathrm{HKm}$ adalah pisang. Pisang banyak disediakan oleh rumah tangga petani HKm diduga karena pisang umumnya dihasilkan dari kebun atau pekarangan sendiri. Selanjutnya gula pasir dan minyak sawit juga cukup banyak disediakan, hal ini diduga karena rumah tangga petani $\mathrm{HKm}$ mempunyai kebiasaan minum kopi manis dan makan makanan selingan (kudapan) berupa pisang goreng. Rata-rata jumlah pangan dan frekuensi penyediaan pangan yang umum dilakukan pada rumah tangga petani HKm disajikan pada Tabel 3.

Bahan pangan yang disediakan untuk anggota rumah tangga petani $\mathrm{HKm}$ dikonversi dalam nilai energi dan protein pangan dengan menggunakan Daftar Komposisi Bahan Makanan yang disusun oleh Direktorat Gizi, Departemen Kesehatan tahun 2004. Untuk mengetahui kualitas keragaman pangan yang tersedia, dianalisis dengan menggunakan pendekatan PPH. Dari data hasil penelitian diketahui bahwa kualitas keragaman pangan pada rumah tangga petani $\mathrm{HKm}$ masih kurang, terlihat dari skor PPH hanya 78 sehingga masih ada selisih 22 untuk menuju ideal. Selanjutnya penyediaan energi pada rumah tangga petani HKm disajikan pada Tabel 4.

Tabel 2. Sebaran Rumah Tangga Petani HKm menurut Frekuensi Strategi Upaya Penghematan dalam Penyediaan Pangan

\begin{tabular}{|c|c|c|c|c|c|c|c|}
\hline \multirow{2}{*}{ No. } & \multirow{2}{*}{ Jenis Strategi } & \multicolumn{2}{|c|}{ Tidak } & \multicolumn{2}{|c|}{ J arang } & \multicolumn{2}{|c|}{ Sering } \\
\hline & & $\mathbf{n}$ & $\%$ & $\mathrm{n}$ & $\%$ & $\mathbf{n}$ & $\%$ \\
\hline 1 & $\begin{array}{l}\text { Membeli makanan yang kurang disukai/ jarang } \\
\text { dikonsumsi/ lebih murah }\end{array}$ & 60 & 66.6 & 27 & 30.0 & 3 & 3.3 \\
\hline 2 & Mengurangi frekuensi makan & 79 & 87.7 & 11 & 12.2 & - & - \\
\hline 3 & Mengurangi jumlah dan jenis pangan yang dikonsumsi & 65 & 72.2 & 22 & 24.4 & 3 & 3.3 \\
\hline 4 & Berpuasa & 85 & 94.4 & 4 & 4.4 & 1 & 1.1 \\
\hline
\end{tabular}

Tabel 3. J enis pangan yang disediakan oleh seluruh rumah tangga petani HKm

\begin{tabular}{clccc}
\hline No & \multicolumn{1}{c}{ Jenis pangan } & $\begin{array}{c}\text { Rata-rata per rumah tangga } \\
\text { (kg/tahun) }\end{array}$ & $\begin{array}{c}\text { Rata-rata per kapita } \\
\text { (kg/kapita/tahun) }\end{array}$ & $\begin{array}{c}\text { Frekuensi } \\
\text { penyediaan*) }\end{array}$ \\
\hline 1 & Beras & 424.6 & 106.2 & Bulanan \\
2 & Mie & 14.5 & 3.6 & Mingguan \\
3 & Tempe & 41.0 & 2.6 & Mingguan \\
4 & Tahu & 33.2 & 8.3 & Mingguan \\
5 & Kangkung & 21.3 & 5.3 & Mingguan \\
6 & Pisang & 121.7 & 30.4 & Mingguan \\
7 & Cabe & 34.4 & 8.6 & Mingguan \\
8 & Tomat rampai & 33.4 & 8.3 & Mingguan \\
9 & Minyak sawit & 47.2 & 11.8 & Bulanan \\
10 & Gula pasir & 61.0 & 15.3 & Bulanan \\
11 & Gula merah & 20.1 & 5.0 & Bulanan \\
12 & Kopi & 19.6 & 4.9 & Bulanan \\
\hline
\end{tabular}

Keterangan : * frekuensi penyediaan yang umum dilakukan oleh sebagian besar (>50\%) rumah tangga petani HKm. 
Tabel 4. Penyediaan energi pada anggota rumah tangga petani $\mathrm{HKm}$

\begin{tabular}{llrrrrrr}
\hline No Kelompok Pangan & $\begin{array}{c}\text { Penyediaan energi } \\
\text { rata-rata (kkal/kapita/hari) }\end{array}$ & \% Total \% AKE Bobot & $\begin{array}{c}\text { Skor *) PPH } \\
\text { aktual }\end{array}$ & $\begin{array}{r}\text { Skor } \\
\text { PPH }\end{array}$ & $\begin{array}{c}\text { Skor PPH } \\
\text { maks }\end{array}$ \\
\hline 1 Padi-padian & 1137 & 49.9 & 51.7 & 0.5 & 25.9 & 25.0 & 25.0 \\
2 Umbi-umbian & 53 & 2.0 & 2.4 & 0.5 & 1.2 & 1.2 & 2.5 \\
3 Pangan hewani & 84 & 3.7 & 3.8 & 2.0 & 7.6 & 7.6 & 24.0 \\
4 Kacang-kacangan & 90 & 4.0 & 4.1 & 0.5 & 2.1 & 2.1 & 5.0 \\
5 Sayur dan buah & 239 & 10.5 & 10.9 & 0.5 & 5.5 & 1.0 & 1.0 \\
6 Minyak dan lemak & 324 & 14.2 & 14.7 & 2.0 & 29.4 & 10.0 & 10.0 \\
7 Buah biji berminyak & 46 & 2.0 & 2.1 & 0.5 & 1.1 & 1.1 & 2.5 \\
8 Gula & 227 & 10.0 & 10.3 & 5.0 & 51.5 & 30.0 & 30.0 \\
9 Lain-lain & 77 & 3.4 & 3.5 & 0.0 & 0.0 & 0.0 & 0.0 \\
\hline Total & 2276 & 100.0 & 103.5 & & 78 & 100.0 \\
\hline
\end{tabular}

Keterangan : ${ }^{*}$ ) skor PPH aktual $=\%$ AKE $\times$ Bobot

Penyediaan pangan kelompok padi-padian sudah melebihi standar ideal, hal ini diduga terkait dengan budaya "belum makan kalau belum makan nasi", sehingga semua rumah tangga petani $\mathrm{HKm}$ selalu menyediakan beras untuk memenuhi kebutuhan makan tiga kali sehari dengan nasi. Penyediaan pangan kelompok sayur dan buah juga di atas standar ideal, hal ini diduga karena rumah tangga petani HKm memproduksi sayur dan buah-buahan yang ditanam secara tumpangsari pada lahan HKm dan pekarangan. Penyediaan pangan kelompok minyak dan lemak, kelompok gula dan kelompok lain-lain juga melebihi standar ideal, hal ini diduga karena kebiasaan setiap hari minum kopi dan makan kudapan berupa gorenggorengan seperti pisang goreng.

Penyediaan pangan kelompok umbi-umbian, pangan hewani, kacang-kacangan, buah biji berminyak masih di bawah standar ideal. Kelompok umbi-umbian dan kacang-kacangan jarang tersedia pada rumah tangga petani $\mathrm{HKm}$, hal ini diduga karena mereka tinggal di sekitar hutan lindung sehingga banyak binatang liar yang merusak tanaman tersebut. Jenis pangan hewani (ikan, daging, telur, susu, dII) jarang disediakan rumah tangga petani $\mathrm{HKm}$. Ikan jarang disediakan karena sedikit se kali rumah tangga petani $\mathrm{HKm}$ yang memiliki kolam ikan, sementara lokasi tempat tinggal mereka jauh dari pasar. Telur biasanya hanya disediakan untuk anak-anak balita dan anak usia sekolah, hal ini diduga karena praktis disiapkan pagi hari sebagai lauk saat makan pagi anak balita dan anak sekolah. Daging ayam, sapi dan kambing hanya disediakan pada harihari tertentu yaitu saat pesta ataupun hari raya. Penyediaan bahan pangan kelompok umbiumbian, kacang-kacangan dan pangan hewani masih harus ditingkatkan.

Salah satu acuan kuantitatif untuk ketersediaan pangan adalah Angka Kecukupan Energi (AKE) rekomendasi Widya Karya Pangan dan Gizi VIII tahun 2004 sebesar 2200 kkal/ kapita/hari. Secara umum kecukupan energi pada rumah tangga petani $\mathrm{HKm}$ sudah terpenuhi (2 276 kkal/ kapita/ hari).

Hanya ada $10 \%$ yang mengalami defisit, yaitu sebanyak $8.9 \%$ defisit ringan dan hanya terdapat $1.1 \%$ rumah tangga petani $\mathrm{HKm}$ yang mengalami defisit sedang. Hal ini diduga karena rumah tangga petani $\mathrm{HKm}$ sudah mampu mencukupi kebutuhan pangan sumber energi. Secara rinci sebaran rumah tangga petani $\mathrm{HKm}$ menurut tingkat kecukupan energi ketersediaan pangan rumah tangga dapat dilihat pada Tabel 5.

Tabel 5. Sebaran Rumah Tangga Petani HKm menurut Tingkat Kecukupan Energi Ketersediaan Pangan Rumah Tangga (kkal/ kapita/ hari).

\begin{tabular}{clccccc}
\hline No & Tingkat kecukupan energi & $\mathbf{n}$ & $\%$ & Rata-rata & Minimum & Maksimum \\
\hline 1 & Defisit berat $(<70 \%)$ & 0 & 0 & 0 & 0 & 0 \\
2 & Defisit sedang $(70-79 \%)$ & 1 & 1.1 & 1743 & 1743 & 1743 \\
3 & Defisit ringan $(80-89 \%)$ & 8 & 8.9 & 1883 & 1786 & 1972 \\
4 & Normal $(90-119 \%)$ & 69 & 76.7 & 2226 & 1983 & 2608 \\
5 & Lebih $(>120 \%)$ & 12 & 13.3 & 2865 & 2627 & 3068 \\
\hline & Total & 90 & 100.0 & 2276 & 1743 & 3068 \\
\hline
\end{tabular}


Zat gizi lain yang penting untuk tubuh adalah protein, digunakan tubuh untuk membentuk sel-sel baru, tanpa protein pertumbuhan tubuh akan terganggu. Tingkat kecukupan protein diperoleh dari perbandingan antara kecukupan protein aktual dibandingkan dengan Angka Kecukupan Protein (AKP) untuk ketersediaan pangan 57 gram/org/hari. Sebaran rumah tangga petani $\mathrm{HKm}$ menurut tingkat kecukupan protein ketersediaan pangan dapat dilihat pada Tabel 6 .

Secara umum kecukupan protein rumah tangga petani $\mathrm{HKm}$ belum terpenuhi (rata-rata masih 51.0 gram/ kapita/ hari). Terdapat $54.4 \%$ rumah tangga termasuk dalam kelompok tingkat kecukupan protein defisit. Kelompok defisit protein pada rumah tangga petani $\mathrm{HKm}$ ini sebagian besar (28.9\%) defisit sedang, $21.1 \%$ defisit ringan dan $4.4 \%$ defisit berat. Pangan sumber protein yang disediakan rumah tangga petani HKm berupa tempe, tahu, ikan segar dan ikan asin, namun ketersediaan pangan ini masih belum mencukupi. Hal ini diduga karena pangan sumber protein sulit didapatkan di sekitar tempat tinggal mereka. Jarak tempat tinggal dengan kota kecamatan tempat pasar berada cukup jauh dan sulit ditempuh sehingga harus menggunakan jasa ojek dengan biaya mahal. Melihat kenyataan ini penyediaan ba- han pangan sumber protein harus ditingkatkan. Rumah tangga petani HKm umumnya mempunyai lahan pekarangan yang cukup luas sehingga penyediaan pangan sumber protein dapat ditingkatkan melalui pemeliharaan hewan ternak berupa ayam, bebek, kambing maupun sapi. Bagi rumah tangga yang mempunyai lahan pekarangan dengan sumber air cukup, dapat meningkatkan penyediaan pangan sumber protein dengan memeli-hara ikan.

\section{Sumber dan Biaya Pangan Rumah tangga Pe- tani $\mathbf{H K m}$}

Pada rumah tangga petani HKm sumber pangan diperoleh dari produksi sendiri, membeli dan lainnya (diberi/barter). Secara rinci sumber dan biaya penyediaan pangan pada rumah tangga petani $\mathrm{HKm}$ menurut kelompok pangan dapat dilihat pada Tabel 7. Dari total pengeluaran pangan pada rumah tangga petani HKm/ kapita/bulan sebesar Rp19 182273 secara umum dapat diketahui $70.8 \%$ sumber pangan berasal dari pembelian, $28.8 \%$ berasal dari produksi sendiri dan $0.4 \%$ berasal dari sumber lain-lain. Tingginya penyediaan pangan yang berasal dari pembelian ini diduga karena sumber pendapatan utama rumah tangga petani $\mathrm{HKm}$ adalah dari usaha non pangan (kopi).

Tabel 6. Sebaran Rumah Tangga Petani HKm menurut Tingkat Kecukupan Protein Ketersediaan Pangan Rumah Tangga (gram/kapita/ hari)

\begin{tabular}{clccccc}
\hline No & \multicolumn{1}{c}{ Tingkat kecukupan protein } & $\mathbf{n}$ & $\%$ & Rata-rata & Minimum & Maksimum \\
\hline 1 & Defisit berat (<70\%) & 4 & 4.4 & 36.0 & 33.4 & 38.3 \\
2 & Defisit sedang (70-79\%) & 26 & 28.9 & 43.2 & 40.3 & 45.1 \\
3 & Defisit ringan (80-89\%) & 19 & 21.1 & 48.6 & 58.9 & 51.4 \\
4 & Normal (90-119\%) & 40 & 44.4 & 58.2 & 70.2 & 70.2 \\
5 & Lebih (>120\%) & 1 & 1.1 & 70.2 & 33.4 & 70.2 \\
\hline
\end{tabular}

Tabel 7. Sumber dan Biaya Penyediaan Pangan Rumah Tangga Petani HKm menurut Kelompok Pangan

\begin{tabular}{|c|c|c|c|c|c|c|c|c|c|}
\hline \multirow{2}{*}{ No } & \multirow{2}{*}{$\begin{array}{c}\text { Kelompok } \\
\text { Pangan }\end{array}$} & \multicolumn{2}{|c|}{ Produksi Sendiri } & \multicolumn{2}{|c|}{ Pembelian } & \multicolumn{2}{|l|}{ Lainnya } & \multicolumn{2}{|l|}{ Total } \\
\hline & & Rupiah/kap/th & $\%$ & Rupiah/kap/th & $\%$ & Rupiah/kap/th & $\%$ & Rupiah/kap/th & $\%$ \\
\hline 1 & Padi-padian & 1502160 & 24.7 & 4580414 & 75.3 & 0 & 0 & 6082574 & 100 \\
\hline 2 & Umbi-umbian & 137600 & 49.9 & 95085 & 34.5 & 42849 & 15.6 & 275534 & 100 \\
\hline 3 & Pangan Hewani & 755781 & 19.5 & 3100748 & 79.8 & 28575 & 0.7 & 3885104 & 100 \\
\hline 4 & Kacang-kacangan & 5292 & 0.7 & 783771 & 99.3 & 0 & 0 & 789063 & 100 \\
\hline 5 & Sayur dan buah & 1818219 & 51.4 & 1721884 & 48.6 & 0 & 0 & 3540103 & 100 \\
\hline 6 & Minyak dan lemak & 0 & 0 & 870195 & 100 & 0 & 0 & 870195 & 100 \\
\hline 7 & $\begin{array}{l}\text { Buah biji } \\
\text { berminyak }\end{array}$ & 150348 & 28.7 & 373191 & 71.2 & 250 & 0 & 523789 & 100 \\
\hline 8 & Gula & 23600 & 1.7 & 1364633 & 98.1 & 2154 & 0.2 & 1390387 & 100 \\
\hline \multirow[t]{2}{*}{9} & Lain-lain & 1137208 & 62.3 & 688316 & 37.7 & 0 & 0 & 1825524 & 100 \\
\hline & Total & 5530208 & 28.8 & 13578237 & 70.8 & 73828 & 0.4 & 19182273 & 100 \\
\hline
\end{tabular}


Rumah tangga petani HKm memenuhi kebutuhan pangan kelompok padi-padian, pangan hewani, kacang-kacangan, minyak dan lemak, buah biji berminyak dan gula sebagian besar berasal dari pembelian. Hal ini diduga karena sebagian besar rumah tangga petani $\mathrm{HKm}$ tidak dapat memproduksi jenis pangan tersebut. Jenis pangan yang sebagian besar diperoleh dari produksi sendiri adalah kelompok umbi-umbian, sayur dan buah dan kelompok lain-lain. Namun jumlahnya masih kurang sehingga perlu ditingkatkan.

\section{KESIMPULAN}

Rumah tangga petani $\mathrm{HKm}$ 78\% merupakan rumah tangga kecil, dengan seluruh kepala dan ibu rumah tangga pada usia produktif, pendidikan setingkat SD, pendapatan/kapita/ bulan adalah Rp509 626 berasal dari usaha $\mathrm{HKm}$ dan non $\mathrm{HKm}$, pengeluaran pangan/ kapita/bulan adalah Rp213 136 dengan penggunaan terbesar untuk penyediaan pangan kelompok padi-padian (31.7\%), sayur dan buah $(20.3 \%)$ dan pangan hewani (18.5\%), sedangkan pengeluaran non pangan adalah sebesar Rp197 851.

Strategi rumah tangga petani $\mathrm{HKm}$ dalam penyediaan pangan melalui upaya peningkatan pendapatan yang umum dilakukan adalah mencari tambahan pendapatan dengan bekerja di luar pekerjaan utama $(54.4 \%)$, beternak (51.1\%), dan menanam tanaman pangan di kebun/lahan pekarangan (46.6\%), sedangkan strategi melalui upaya penghematan jarang dilakukan.
Penyediaan pangan sumber energi pada rumah tangga petani HKm yang sudah mencukupi adalah kelompok padi-padian (1 $137 \mathrm{kkal} /$ kapita/hari), kelompok sayur dan buah (239 kkal/kapita/ hari), kelompok minyak dan lemak (324 kkal/kapita/hari), kelompok gula (227 kkal/kapita/hari) dan kelompok lain-lain (77 kkal/kapita/hari). Sementara itu penyediaan pangan sumber energi yang masih belum mencukupi adalah kelompok umbi-umbian (53 kkal/kapita/hari), kelompok pangan hewani (84 kkal/kapita/hari), kelompok kacang-kacangan (90 kkal/kapita/hari), dan kelompok buah bij i berminyak (46 kkal/ kap/ hari).

Sumber dan biaya penyediaan pangan rumahtangga petani $\mathrm{HKm}$ sebagian besar (70.8\%) berasal dari membeli, $28.2 \%$ berasal dari produksi sendiri, dan $0.4 \%$ berasal dari sumber lainnya.

\section{DAFTAR PUSTAKA}

[BPS] Biro Pusat Statistik. 2008. Perkembangan Beberapa Indikator Utama SosialEkonomi Indonesia, J akarta.

[DEPKES] Departemen Kesehatan. 2004. Daftar Komposisi Bahan Makanan. Direktorat Gizi, Departemen Kesehatan, J akarta.

Puspitawati H. 1998. Proverty Level and Conflicts Over Money Within Families. Master's Theses. Departemen of Sociology, College of Agriculture IOWA Stage University, USA. 